\title{
Diploposthe laevis (Bloch) Jacobi (Eucestoda, Hymenolepididae) from Netta peposaca (Vieillot) (Aves: Anatidae): first record for the Neotropical Region and a new host ${ }^{1}$
}

\author{
Eliane F. da Silveira ${ }^{2,3} \&$ Suzana B. Amato $^{3}$ \\ ${ }^{1}$ Contribution number 527 of the Departamento de Zoologia, Universidade Federal do Rio Grande do Sul. \\ ${ }^{2}$ Departamento de Biologia, Museu de Ciências Naturais, Universidade Luterana do Brasil. 92425-900 Canoas, Rio Grande \\ do Sul, Brasil. E-mail: elianefraga3@hotmail.com \\ ${ }^{3}$ Departamento de Zoologia, Instituto de Biociências, Universidade Federal do Rio Grande do Sul. Caixa Postal 15014, \\ 91501-970 Porto Alegre, Rio Grande do Sul, Brasil.E-mail: sbamato@ufrgs.br
}

\begin{abstract}
One hundred eight rosy-billed pochards, Netta peposaca (Vieillot, 1816), collected in Brazil and Argentina were examined for endoparasites. Collection sites included the municipalities of Santa Vitória do Palmar and Jaguarão, Rio Grande do Sul State, Brazil (wintering site) and Alvear, Corrientes Province, northern Argentina (nesting site). Birds were frozen in dry ice after collection. During necropsy they were categorized according to sex and maturation, either adult or juvenile. The cestode Diploposthe laevis (Bloch) Jacobi, 1896 was found (prevalence $68.5 \%$, mean infection was 2). The mean prevalence of D. laevis in Alvear (25.9\%) was higher than found in Jaguarão and Santa Vitória do Palmar, Rio Grande do Sul (19\%), and could be related to the nesting site and to the period when the birds may ingest a higher amount of food. This is the first record of a species of the genus Diploposthe in anatideans from South America, and the first record of the species in N. peposaca. Details of the cirrus pouch and vagina were described based on histological sections.

KEY WORDS. Argentina; Brazil; migratory flyway; nesting site; rosy-billed pochard; wintering site.
\end{abstract}

RESUMO. Diploposthe laevis (Bloch) Jacobi (Eucestoda: Hymenolepididae) em Netta peposaca (Vieillot) (Aves, Anatidae): primeiro registro para Região Neotropical e novo hospedeiro. Com o objetivo de conhecer a helmintofauna do marrecão, Netta peposaca (Vieillot, 1816), na América do Sul, 108 aves foram amostradas. Os pontos de captura foram os municípios de Santa Vitória do Palmar e Jaguarão, no Estado do Rio Grande do Sul, sul do Brasil (pólo de invernia), e em Alvear, Província de Corrientes, região norte da Argentina (pólo de nidificação), entre 2002 e 2004. As aves foram congeladas em gelo seco logo após o abate. Durante o procedimento de necropsia tiveram o sexo identificado, e foram classificadas de acordo com estado de maturação sexual, em juvenil e adulto. O cestóide Diploposthe laevis (Bloch) Jacobi, 1896 foi encontrado com prevalência média de $68,5 \%$ e intensidade média de infecção de dois espécimes por hospedeiro. $A$ prevalência média de $D$. Iaevis em Alvear (25,9\%) foi maior do que a encontrada em Jaguarão e Santa Vitória do Palmar, Rio Grande do Sul (19\%) fato que pode estar relacionado ao pólo de nidificação e ao período onde as aves devem ingerir um maior volume de alimento. Este é o primeiro registro de uma espécie do gênero Diploposthe em anatídeos na América do Sul, e o primeiro registro desta espécie em $N$. peposaca. Detalhes da bolsa do cirro e a vagina foram descritos com base em cortes histológicos.

PALAVRAS-CHAVE. Argentina; Brasil; marrecão; pólo de invernia; pólo de nidificação; rota de migração.

The genus Diploposthe was proposed by Jacobi in 1896 to include cestodes that presented bilateral genital openings and were found as parasites of anatideans, but identified by Bloch, in 1782, as Taenia laevis. In 1897, while identifying specimens collected from Aythya ferina Linnaeus, 1758, Jacobi suggested a new delineation and specimens identified as T. laevis were changed to Diploposthe laevis (Bloch) Jacobi, 1896, a type species of the genus (Skrjabin \& Mathevossian 1941).
Sulgostowska (1977) redescribed D. laevis and Diploposthe bifaria (Siebold in Creplin, 1846) collected from A. ferina and Aythya nyroca Güld, in Poland, revising the genus Diploposthe. Based on the material collected from ducks, SulgosTowsKa concluded that the genus Diploposthe had two species: the monoecious D. laevis and the dioecious D. bifaria. This characteristic could have led to a misidentification of some species in this genus.

Revista Brasileira de Zoologia 25 (1): 83-88, March, 2008 
Few studies have been carried out with cestodes parasitizing anseriformes. MeggitT (1927) recorded the species D. laevis from Fulix cristata Linnaeus, collected in Egypt. Mathevossian (1942) identified cestodes collected from the anatideans Nyroca rufa (Gmelin, 1789) and Netta rufina (Pallas, 1773), described them as Diploposthe skrjabini Mathevossian, 1942 and Diploposthe sp., and emended the genus Diploposthe, suggesting a dichotomous key having as a main diagnostic character the number of testes. SCHILlER (1951) studied cestodes parasitizing anseriformes from Wisconsin, USA, and recorded D. laevis from Spatula clypeata Linnaeus, 1758 and Aythya americana (Eyton, 1838). SINGH (1959) described cestodes in the families Amabiliidae Braun, 1900, Diploposthidae Poche, 1926, and Progynotaeniidae Fuhrmann, 1936 collected from birds in India. CZAPLINSKI (1956) published a detailed work about the hymenoleptidean fauna of wild and domestic anseriformes from Poland, but did not include in the species description the number of testes as suggested by Mathevossian (1942). Since this important character was not observed, he concluded that Diploposthe sp., described by Mathevossian, was identical to D. laevis. Noseworthy \& Threlfall (1978) examined specimens of Aythya collaris (Donovan, 1809) collected in Ontario, Canada and found $97 \%$ of the hosts parasitized by cestodes, with $D$. laevis presenting a prevalence of $25 \%$. McLaughuIN \& Burt (1979) investigated hymenoleptidean cestodes of 12 species of anatideans from New Brunswick, Canada and recorded 21 species, including D. laevis, parasitizing the intestine of $A$. collaris. IllesCAS Gomez (1982) made the first record of D. laevis parasitizing A. ferina and N. rufina in Spain.

AHern \& SCHMidt (1976) revised the description of the family Acoleidae Fuhrmann, 1906 and proposed the extinction of the family Diploposthidae, placing the genera Acoleus Fuhrmann, 1899; Diploposthe; Diplophallus Fuhrmann, 1900; Jardugia Southwell \& Hilmy, 1929, and Himantocestus Ukoli, 1965 in the family Acoleidae. The validity of this family and its genera is contested by several authors. Scнмidт (1986) accepted the family Acoleidae with four genera: Acoleus, Diploposthe, Diplophallus, and Jardugia. However, Khalil (1994) included Acoleus and Diplophallus in this family, with the genera Diploposthe and Jardugia being placed in the family Hymenolepididae Ariola, 1899.

In the present work, D. laevis is recorded for the first time in South America, and Netta peposaca (Vieillot, 1816) is a new host for the species. Additionally, detailed description is provided demonstrating the existence of a muscle layer around the cirrus pouch as well as histological sections showing details of the vagina, structures that have not been investigated in previous descriptions.

\section{MATERIAL AND METHODS}

A total of 108 rosy-billed pochards ( $N$. peposaca) were captured by shot gun, with permission of the Instituto Brasileiro do Meio Ambiente e Recursos Naturais Renováveis (Ibama nº 042/ 2004/RS) in the Municipality of Santa Vitória do Palmar $\left(33^{\circ} 16^{\prime} 13^{\prime \prime} \mathrm{S}, 53^{\circ} 26^{\prime} 28^{\prime \prime} \mathrm{W}\right)$ - locality of Fazenda Sossego $\left(33^{\circ} 16^{\prime}\right.$

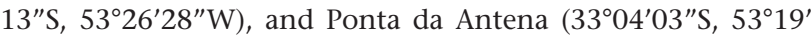
$\left.20^{\prime \prime} \mathrm{W}\right)$, in Jaguarão Municipality (32 $37^{\prime} 53^{\prime \prime}$ S, 5309'3,6"W), State of Rio Grande do Sul, southern Brazil, and in Alvear, Santa Vitória do Palmar Province of Corrientes, northern Argentina $\left(29^{\circ} 09^{\prime} 13^{\prime \prime} \mathrm{S}, 56^{\circ} 54^{\prime} 34^{\prime \prime} \mathrm{W}\right)$. The birds were collected between 2003 and 2004. After being killed, the animals were frozen in dry ice, and in the laboratory separated by sex and maturation stage (juveniles or adults) based on presence/absence of the Fabricius bursa. Cestodes were fixed in A.F.A., stained with Delafield hematoxylin, and mounted in Canadian balsam mounting medium (Амато et al. 1991). The hooks from the rostellum were removed and mounted in de Faure's (deF) mounting medium (Амато et al. 2003). All measurements are in micrometers ( $\mu \mathrm{m})$, or otherwise indicated. Mean, standard deviation and number of specimens measured for a determined character appear in parentheses when different from the established number. Ecological terms were used according to BusH et al. (1997). Photomicrographs were taken using a Zeiss Axiolab microscope equipped with phase contrast. Bird carcasses were deposited in the "Coleção Ornitológica do Museu de Ciências Naturais (MCN), Fundação Zoobotânica do Rio Grande do Sul", Porto Alegre, Rio Grande do Sul, Brazil. Representative specimens of the cestode were deposited in the "Coleção Helmintológica do Instituto Oswaldo Cruz (CHIOC)”, Rio de Janeiro, Brazil.

\section{RESULTS}

\section{Diploposthe laevis (Bloch, 1782) Jacobi, 1896}

\section{Figs $1-9$}

Description. Based on 12 specimens mounted in toto. Hymenolepididae, Diploposthinae. Delicate scolex triangular, 100-200 (146.4, 40.2; $\mathrm{n}=7)$ long and 110-160 (133.7, 16; $\mathrm{n}=$ 6) wide (Fig. 1). Four circular suckers, without hooks 47.5-65 $(53.5,6.9 ; \mathrm{n}=5)$ long and 37.5-47.5 (41.5, 4.5; $\mathrm{n}=7)$ wide. Rostellar pouch terminates after the posterior end of the suckers; retractile rostellum 36.7-296 $(140,22 ; n=9)$ long, with 10 arcuatoid hooks in a single row, 19.9-25.6 $(22.7,1.1 ; \mathrm{n}=10)$ long (Fig. 2). Strobila long with pronounced external segmentation; maximum total length of the strobila $296 \mathrm{~mm}$ (159 mm, 81.6; $\mathrm{n}=9)$, width varying between $0.05-2.3 \mathrm{~mm}(1.3 \mathrm{~mm}, 0.64$; $\mathrm{n}=140)$ in immature proglottids; $0.24-3.75(0.82,0.2 ; \mathrm{n}=124)$ in male mature proglottids; $2.2-4.7(3,5,0,55 ; \mathrm{n}=111)$ in female mature proglottids; $2.9-5.8(4.0,0.8 ; \mathrm{n}=80)$ in gravid proglottids. Proglottids craspedote, transversally elongated.

Male reproductive system with a double set of male reproductive organs per proglottid (Fig. 3). Testes 75-200 (148.1, 41.2; $\mathrm{n}=20$ ) in diameter, usually present in triplicate, but two or four testes could also be found in central area, dorsal and near to posterior border of proglottid. Testes round or oval in young proglottids and irregular in mature ones. Bilateral genital pores in middle of lateral margin of proglottid (Fig. 8). Cirrus was covered by spines 142.5-212.5 $(185,20 ; \mathrm{n}=13)$ long; 47-95 $(744.4,284.9 ; \mathrm{n}=17)$

Revista Brasileira de Zoologia 25 (1): 83-88, March, 2008 

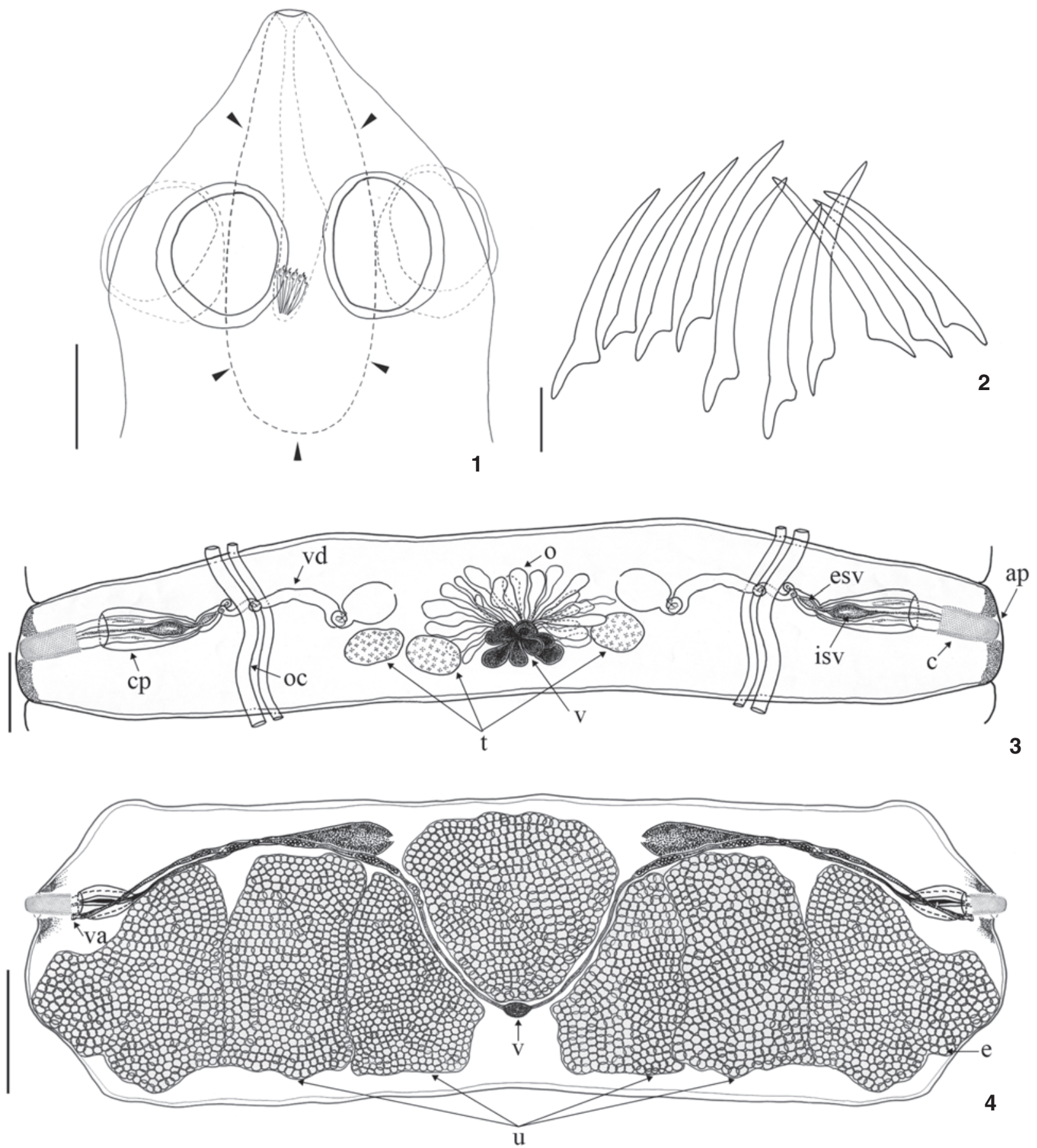

Figures 1-4. Diploposthe laevis: (1) scolex and rostellar pouch extending posterior to suckers (head arrows), bar = $10 \mu \mathrm{m}$; (2) ten arcuate rostellar hooks, bar $=2.5 \mu \mathrm{m}$. Proglottids of D. laevis: (3) diagram of mature proglottid (dorsal view), showing a double set of male and female ducts per proglottid. Testes in the central area on the dorsal side, near to posterior border of proglottid ( $t$ ), bilateral atrium pore (ap), cirrus covered by a layer of spines (c), cirrus pouch (cp), seminal vesicles: internal (isv) and external (esv), vas deferens (vd), dorsal to the osmoregulatory canals (oc), ovary with fingerlike projections (o), vitellarium (v), bar = $200 \mu \mathrm{m}$; (4) gravid proglottid (dorsal view), showing the double vagina (va), forming seminal receptacles and vitellarium (v), uterus (u) in gravid proglottids forming pouches filled with eggs (e), bar $=50 \mu \mathrm{m}$. 


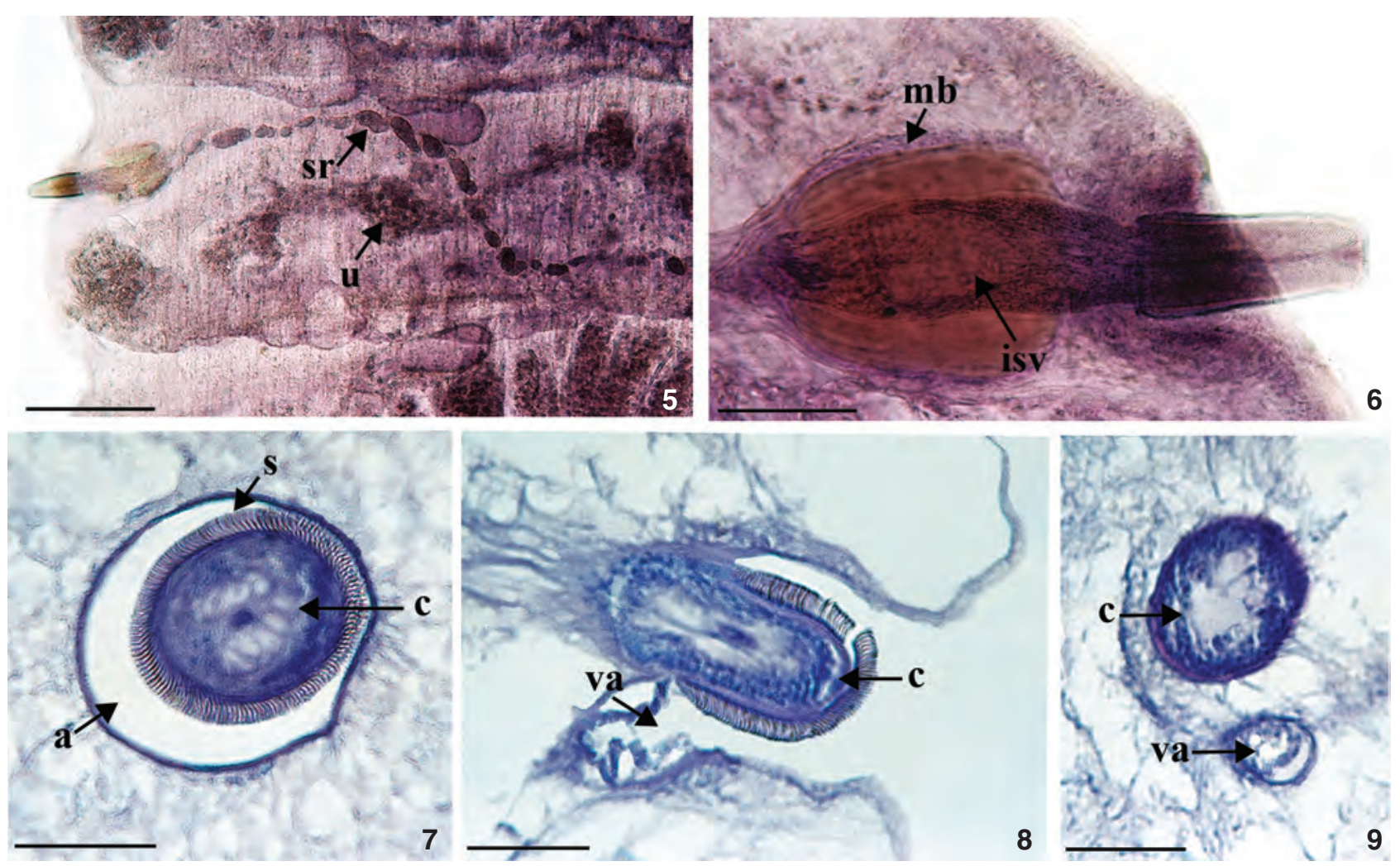

Figures 5-9. Gravid proglottid of Diploposthe laevis: (5) photomicrograph showing the vagina forming seminal receptacles (sr) and uterus (u) filled with eggs, (6) muscle layer around the cirrus pouch (mb), internal seminal vesicle (isv), bar = 50 $\mu \mathrm{m}$; (7) histological section of the proglottid showing the atrium (a) and cirrus (c) with a layer of spines (s) indicates by arrow, bar $=50 \mu \mathrm{m}$; (8) histological section showing the atrium with separate genital pores, where cirrus is extroverted (c) and vagina, with a dilated aperture (va) indicated by arrow, bar $=50 \mu \mathrm{m}$; (9) histological section showing the vagina (va) bellow the male pore with cirrus extroverted (c), bar $=50 \mu \mathrm{m}$.

wide (Figs 1 and 7). Cirrus pouch oval 162-500 (356.3, 96.8; $\mathrm{n}=$ 13) long; 52.5-110 (80.9, 14.1; $\mathrm{n}=13)$ wide (Fig. 3). Conspicuous muscular layer around the cirrus pouch 112.5-462 (266.7, 111.7; $\mathrm{n}=13)$ long; 62.5-180 (130, 33.4; $\mathrm{n}=13)$ wide (Figs 3 and 6). Internal and external seminal vesicles present; external seminal vesicle piriform laterally to ovary, near to the anterior border of gravid proglottids (Figs 3 and 4). Vas deferent between seminal vesicles and cirrus pouch, forming a dorsal loop to the osmoregulatory canals (Fig. 3). Female reproductive system is a single set of reproductive organs per proglottid, with exception of double vagina (Figs 3 and 4). Ovary lobed, mediane, equatorial to anterior end of proglotiid; lobes 300-1230 $(744.4,284.8 ; \mathrm{n}=17)$ long (Fig. 3). Vitellarium post-ovarian lobed, 110-550 (332.3, 134.3; n $=16$ ) long (Fig. 3). Vagina run towards genital pores in margin of proglottid, ventrally to cirrus pouch and to vas deferent, but sometimes covered these two structures (Figs 4 and 5). Vagina forming seminal receptacles, open lateroventral to cirrus (Fig. 5). The uterus saccular extanding transversally; in mature proglottids it was below the cirrus pouch, passing osmorregulatory canals; in gravid proglottids it form sacs filled with eggs that occupied the entire space; 35-40 long, 30-39 wide (Fig. 4).

Double genital pores in the middle anterior portion of lateral border of proglottid. Genital pores opening in a atrium (Figs 7 and 8).

\section{TAXONOMIC SUMMARY}

Synonym: Taenia laevis Bloch, 1782; Taenia bifaria Siebold (Creplin, 1846); Taenia trichosoma Linstow, 1882; Taenia tuberculata Krefft, 1871; Diploposthe lata Fuhrmann, 1900; Diploposthe matevossianae Rysavý, 1961.

Host: Netta peposaca (Vieillot, 1816) - new host record.

Host specimens deposited: $\mathrm{MCN} \mathrm{N}^{\circ}$ s 2775 - male; 2776 female.

Localities: Fazenda Sossego and Ponta da Antena, Santa Vitória do Palmar, and Jaguarão, Rio Grande do Sul, southern Brazil; and Alvear, Corrientes Province, northern Argentina.

Site of infection: Intestine (anterior jejunum-ileum).

Prevalence: $68.5 \%$.

Mean intensity of infection: 2 .

Voucher specimens deposited: CHIOC 36967.

Revista Brasileira de Zoologia 25 (1): 83-88, March, 2008 


\section{REMARKS}

Diploposthe laevis has been referred to by several authors as a species commonly present in anseriformes (SINHG 1959, JARECKA 1960, SulgostowsKa 1977, Illescas Gomes 1982). Tapeworms collected from $N$. peposaca were identified as D. laevis because they presented double ducts and genital pores, a cirrus covered by spines, and three testes per proglottid. In addition, the ovary and vitellarium with lobes pre-testicular, and rostellum with ten arcuatoid hooks in a single row.

The taxonomic position of this species was discussed by Ahern \& SCHMidT (1976) and CZAPLINSKI \& VAuCher (1994). In the present work, we agree with the suggestion of CZAPLINSKI \& VAUCHER (1994) that included D. laevis in the family Hymenolepididae due to the presence of three testes per proglottid, and in the subfamily Diploposthinae for having double terminal genitalia. This taxonomic position is also a consensus for SulgostowsKA (1977), Mclaughlin \& Burt (1979), and Illescas Gomez (1982).

Specimens studied in this work presented some differences when compared with previous descriptions. Diploposthe laevis from $N$. peposaca was smaller $(296 \mathrm{~mm}$ ) than those reported by Beverley-Burton (1962), McLaughlin \& Burt (1979), and Illescas Gomez (1982), 444, 250, and $400 \mathrm{~mm}$, respectively, this difference could be related to developmental stage of the specimens. Rostellar hooks of $D$. laevis from $N$. peposaca were longer (19.9-25.6) than the ones found by BeVErLey-Burton (1962), Sulgostowska (1977), and Illescas Gomez (1982), however, our measurements are similar to the ones found by McLaughlin \& Burt (1979). In most of the examined specimens of $D$. laevis the number of testes observed was three, sometimes were two or four testes per proglottid. According to Mathevossian (1942) the number of testes is a character used to differentiate species. This author suggested that specimens presenting 14 to 17 testes belonged to the species D. skrjabini, while the ones presenting three testes were identified as D. laevis, and specimens presenting six testes would belong to a new, non-identified species. CzAPLINSKI (1956) found specimens with 3-7 testes per proglottid in the same strobila, therefore the author considered that the species of Diploposthe described by Mathevossian (1942) was D. laevis, with a later support from Mclaughlin \& Burt (1979) and Illescas Gomez (1982). Illescas Gomez (1982) reported that D. skrjabini presents a higher number of testes than is described for the family Hymenolepididae, since in this family usually there are less than four testes per proglottid. However, when CzAPLInski \& VAUChER (1994) presented a diagnosis for the family Hymenolepididae, they appointed that the number of testes was usually three, and mentioned that 32 testes were exceptionally found. Also, one to seven testes have been found in species that normally present only three. In the present study, as described by IlLESCAS GoMEz (1982), we observed three testes (rarely four) per proglottid. The cirrus pouch presented a maximum length $(500 \mu \mathrm{m})$ similar to the observed by McLaughlin \& Burt (1979), and it was longer than the one recorded by Beverley-Burton (1962), Sulgostowska (1980), and Illescas Gomez (1982).

Specimens of D. laevis collected from $N$. peposaca presented a conspicuous muscle layer surrounding the cirrus pouch (Fig. 5) as reported by CZaplinski (1956) and Beverley-Burton (1962), however the latter author observed this muscle layer, but did not present any drawing or photograph. Illescas Gomez (1982) presented drawings showing the layer, but did not comment on its existence in the morphological characterization of the species. Sulgostowska (1977) also did not present any drawings of the muscle layer. McLaughlin \& BurT (1979), following the other studies, did not mention the existence of this musculature. Recently, CzAPLINSKI \& VAUCHER (1994) presented a dichotomous key for the species in the family Hymenolepididae parasites of birds and mammals, a valuable contribution to helminthology. The species D. laevis was considered by these authors as the type species in the genus. In the subfamily and genus diagnosis, CZAPLINSKI \& VAUCHER (1994) did not mention the muscle layer that surrounds the cirrus pouch, and used drawings of $D$. laevis published by Sulgostowska (1977) which did not show this character.

In specimens observed in the present study, the ovary presented fingerlike lobes (110-1230), according to description made by Sulgostowska (1977), McLaughuin \& Burt (1979), and Illescas Gomez (1982). The width of the ovary is according to Mclaughlin \& Burt (1979), and larger than recorded by Sulgostowska (1977) and Illescas Gomez (1982). The vagina forms a dilatation at the end and opens at the base of the cirrus (Figs 7 and 8). These details have not been cited or recorded by other authors until now, possibly due to the lack of good material and to the need of histological preparations for study.

Seventy-four of 108 examined birds were infected by $D$. laevis, equivalent to a prevalence of $68.5 \%$. From the total infected birds, $12.9 \%$ were juvenile females, $12 \%$ adult females, $11 \%$ juvenile males, and 32\% adult males. CzAPLINSKI (1956) observed lower prevalence values for N. ferina (50\%), N. rufa (56.5\%) e Anser anser (Linnaeus, 1758) (0.4\%); however, in the first two species the infection intensity was very high 5-299, and 1-840, respectively. SulgostowsKa (1977) examined 75 specimens of $A$. ferina and $A$. nyroca, finding 73 infected with $D$. laevis, and a prevalence of 97\%. As described by JARECKA (1960) and Sulgostowska (1977), specimens of D. laevis parasitizing $N$. peposaca, were found in pairs inside the intestine. According to the authors, D. laevis and D. bifaria could influence the colonization of the habitat by other parasites, not allowing infrapopulations greater than two individuals.

In previous studies performed with $D$. laevis, there was no information about parasite prevalence related to sex or age of the host birds. Samples analyzed in the present study, revealed a higher prevalence of $D$. laevis in adult males when compared to adult females or juveniles from both sexes. This observation suggests that adult males could be ingesting a higher number of the intermediate hosts. JARECKA (1958) per- 
formed experiments about the biological cycle of these cestodes and concluded that copepods could be considered intermediate hosts for $D$. laevis and D. skrjabini. This relationship could explain the variation found in prevalence for different localities in the present study. Alvear, Northern Argentina presented the highest prevalence $(25.9 \% ; n=29)$, followed by Jaguarão, Rio Grande do Sul, Brazil (19\%; n = 27), Santa Vitória do Palmar, Rio Grande do Sul, Brazil $(19 \% ; n=23)$ sites near to the coastal region of the state, and Rio Pardo, Roi Grande do Sul, Brazil $(5.4 \% ; n=29)$ in the central region of the state. The presence of two large lagoons (Patos and Mirim) in the coastal zone of Rio Grande do Sul State, permitted contact with the intermediate host, which may explain the high prevalence of infected birds in this region. The high prevalence in Alvear, Argentina could be related to the fact that this region is one of the nesting sites for this bird, a period of high food ingestion.

\section{ACKNOWLEDGEMENTS}

To Ibama for the license to capture the hosts; João O. Meneghetti, Departamento de Zoologia, Instituto de Biociências, Universidade Federal do Rio Grande do Sul, for ornithological information; hunters Jair Nunes and Sidnei A. Bavaresco for the capture of the birds; João A. Maciel and Simone de A. Gomes for allowing the development of our work in their property (Fazenda Sossego), and Dr Philip J. Scholl for reviewing the English text.

\section{LITERATURE CITED}

Ahern, W.B. \& G.D. Schmidt. 1976. Parasitic helminthes of the American avocet Recurvirostra americana: four new species of the families Hymenolepididae and Acoleidae (Cestoda: Cyclophyllidae). Parasitology 73: 381-398.

Amato, J.F.R.; S.B. Amato \& L.C.C. Daudt. 2003. New species of Temnocephala Blanchard (Platyhelminthes, Temnocephalida) ectosymbiont on Aegla serrana Buckup \& Rossi (Crustacea, Anomura) from Southern Brazil. Revista Brasileira de Zoologia 20 (3): 493-500.

Amato, J.F.R.; W.A. Boeger \& S.B. Amato. 1991. Protocolos para laboratório: coleta e processamento de parasitos de pescado. Seropédica, Gráfica da Universidade Federal Rural do Rio de Janeiro, 81p.

Beverley-Burton, M. 1962. Studies on the Cestoda of British freshwater birds. Proceedings of the Zoological Society of London 142: 307-346.

Bush, A.; K.D. Lafferty; J.M Lotz \& A.W. Shostak. 1997. Parasitology meets ecology on its own terms: Margolis et al. revisited. Journal of Parasitology 83: 575-583.

Czaplinski, B. 1956. Hymenolepididae Fuhrmann, 1907 (Cestoda) parasites of some domestic and wild Anseriformes in Poland. Acta Parasitologica Polonica 4 (8): 175-373.

Czaplinski, B. \& C. Vaucher. 1994. Family Hymenolepididae Ariola, 1899, p. 595-663. In: L.F KhaliL; A. Jones \& R.A. BraY (Eds).
Keys to the Cestode Parasites of Vertebrates. Wallingford, CABI International, VII+768p.

Illescas Gomez, P. 1982. Diploposthe laevis (Bloch, 1782) Jacobi, 1896 (Diploposthidae Poche, 1926); parasito de aves Anseriformes procedentes del Coto de Doñana. Revista Iberica de Parasitologia 42 (3): 267-276.

JARECKA, L. 1958. Plankton crustaceans in the life cycle of tapeworms occurring at Druzno Lake. Acta Parasitologica Polonica 6 (2): 65-109.

JARECKA, L. 1960. Separation of sexes and quantitative regulation in Cestodes of the genus Diploposthe Jacobi, 1896 (CestodaDiplopostidae). Bulletin de L'Académie Polonaise des Sciences 8 (4): 155-157.

KhaLIL, L.F. 1994. Family Acoleidae Fuhrmann, 1899, p. 387389. In: L.F Khalil; A. Jones \& R.A. Bray (Eds). Keys to the Cestode Parasites of Vertebrates. Wallingford, CABI International, VII+768p.

Mathevossian, E.M. 1942. An analysis of the specific components of the genus Diploposthe: Cestodes from Anatidae. Comptes Rendus (Doklady) de L'Académie des Sciences de L'URSS 24 (9): 265-268.

McLaughuin, J.D. \& M.D.B. Burt. 1979. Studies on the hymenolepid cestodes of waterfowl from New Brunswick, Canada. Canadian Journal of Zoology 57: 34-79.

MegGitT, F.J. 1927. Report on a collection of Cestoda, mainly from Egypt. Part II. Cyclophyllidea: Family Hymenolepididae. Parasitology 19: 420-450.

Noseworthy, S.M. \& W. Threlfall. 1978. Some metazoan parasites of ring-necked ducks, Aythya collaris (Donovan), from Canada. Journal of Parasitology 64 (2): 367-368.

SCHILLER, E.L. 1951. The cestoda of Anseriformes of the North Central States. American Midland Naturalist 46 (2): 444-461.

SснміDT, G.D. 1986. Handbook of tapeworm identification. Boca Raton, CRC Press, 675p.

SINGH, K.P. 1959. Some avian cestodes from India. IV. Species belonging to families Amabiliidae, Diploposthidae and Progynotaeniidae. Indian Journal of Helminthology 11 (2): 63-74.

Skrjabin, K.I. \& E.M. Mathevossian. 1941. On the revision of the taxonomy of the cestodes belonging to the family Hymenolepididae. Comptes Rendus (Doklady) de L'Académie des Sciences de L'URSS 23 (4): 333-336.

Sulgostowska, T. 1977. Redescription of the species Diploposthe laevis (Bloch, 1782) and D. bifaria (Siebold in Creplin, 1846) and revision of the genus (Cestoda, Hymenolepididae). Acta Parasitologica Polonica 24 (23): 231-248.

Sulgostowska, T. 1980. The development of organ systems in cestodes. III. Histology of Diploposthe laevis (Bloch, 1782) and D. bifaria (Siebold in Creplin, 1846) (Hymenolepididae) and histogenesis of their reproductive system. Acta Parasitologica Polonica 24 (16): 143-152.

Received in 19.VII.2007; accepted in 20.II.2008. 